FACTA UNIVERSITATIS

Series: Mechanical Engineering Vol. 14, No 1, 2016, pp. 101 - 111

Original scientific paper

\title{
EXPERIMENTAL FORCED SOLAR THIN LAYER GINGER DRYING
}

UDC 662.6

\author{
Mahesh Kumar \\ Mechanical Engineering Department, \\ Guru Jambheshwar University of Science \& Technology, India
}

\begin{abstract}
In this research paper, the convective and the evaporative heat transfer coefficients of ginger (zingiber officinale) drying in an indirect solar cabinet dryer under the induced forced convection mode is presented. Experiments were conducted during the month of March 2015 under the climatic conditions of Hisar, India (29'5' '5 'N latitude and 75'45'55" $E$ longitude). The experimental data obtained for solar drying of a constant ginger mass of $150 \mathrm{~g}$ has been used to determine constants ' $C$ ' and ' $n$ ' in the Nusselt number expression using linear regression analysis; consequently, the convective and the evaporative heat transfer coefficients have been evaluated. The average value of constants ' $C$ ' and ' $n$ ' were evaluated as 0.999 and 0.318 , respectively. The average values of the convective and the evaporative heat transfer coefficients were found to be $3.95 \mathrm{~W} / \mathrm{m}^{2}{ }^{\circ} \mathrm{C}$ and $160.47 \mathrm{~W} / \mathrm{m}^{2}{ }^{\circ} \mathrm{C}$, respectively, for the given mass samples of ginger. The average collector efficiency was observed to be $14.5 \%$. The experimental error in terms of percentage uncertainty was found to be $20.87 \%$.
\end{abstract}

Key Words: Ginger Drying, Indirect Forced Solar Dryer, Convective Heat Transfer Coefficient, Evaporative Heat Transfer Coefficients, Collector Efficiency

\section{INTRODUCTION}

India is the largest producer of ginger (an herb obtained from zingiber officinale) in the world accounting for about one-third of the total world output followed by China, Nigeria, Indonesia, Bangladesh and Thailand [1]. Ginger believed to have originated in South-East Asia and is used worldwide as a spice for flavoring a multitude of food varieties and products. It is also used in medicine, particularly in traditional medicine of India. Drying is

Received: August 14, 2015 / Accepted: December 2, 2015

Corresponding author: Mahesh Kumar

Guru Jambheshwar University of Science \& Technology, Hisar - 125001, Haryana, India

E-mail: mk_shandilya@yahoo.com 
essentially important for preservation of ginger for future use by removing enough moisture from it in order to avoid its decay and spoilage. The ginger dried in open sun is dependent on the availability of sunshine; it requires large space and a long drying time and is susceptible to contamination. Solar drying is one of the most promising alternatives to the open sun drying which can be used in developing countries.

The performance of the forced convection solar dryer was compared to the electrically operated tray type mechanical dryer for drying of groundnut, ginger, and garlic. It is found that cost benefit ratio for solar dryer was higher [2]. The dried ginger quality was reported better and the drying time was observed as less in a solar hybrid dryer than in the open sun drying (OSD) [3]. The best quality dried ginger in the shortest drying time was obtained from the heat pump dehumidified dryer and the mixed mode solar dryer than the tray dryer [4]. The heat pump dehumidified ginger drying incorporated by the two stage-drying could reduce the drying time by $59.32 \%$ at $40{ }^{\circ} \mathrm{C}$ [5]. The ginger drying is found experimentally faster with the solar dryer than with the open air method [6]. A forced convective cabinet dryer was used for single layer ginger drying at different drying air temperatures at a fixed air velocity [7]. The photovoltaic powered indirect forced convection solar dryer was developed for drying ginger [8]. The quality of dried ginger was improved and the drying time was observed to be reduced by $66.7 \%$ against OSD. The drying kinetics of ginger rhizomes under blanched and non-blanched conditions were studied by using the hybrid solar dryer and the mechanical tray dryer [9]. The Page equation was found to be the best among the five thin layer drying models to predict the moisture content of the thin layered sliced ginger. The thin layer solar drying of ginger was studied with a different mass flow rate and the page model was found as the most appropriate for representing the ginger drying curve [10]. The solar drier with evacuated tube collectors was designed for drying ginger [11]. The drying kinetics of pre-treated and untreated ginger at selected temperatures and at a constant air velocity was investigated [12]. The drying time of pre-treated ginger was found shorter than the untreated one and the Page model was reported to be best suited to describe the drying kinetics of ginger. The performance of an indirect forced convection solar dryer integrated with a thermal storage for drying ginger was studied [13]. The average efficiency of the dryer was reported to be $30 \%$. Drying characteristics of ginger rhizomes sliced to various lengths and the whole ginger were studied under sun drying, solar tunnel drying and cabinet tray drying at different temperatures [14]. The moisture content was observed to be reduced from 81.3 to $10 \%$ and slicing of ginger significantly reduced the drying time in all the drying methods. A mixed mode solar cabinet dryer was used to study the drying characteristics of ginger which was observed as better for ginger drying in aspects of quality, drying time, and power requirement as compared to OSD [15].

In developing countries, the open sun drying is a popular and economical method used for drying and preservation of agricultural and food products. But it has a number of drawbacks which include degradation of product quality by wind-blowing, debris, rain, insects, and animals. To avoid these problems a solar dryer consisting of a box shaped housing unit having a transparent sunlight cover was developed. Afterwards, many researchers have made several improvements in the solar drying technology utilizing natural convection circulation, forced convection circulation, and auxiliary source heating (i.e., electricity and fossil fuels) to achieve the desirable drying features. In the forced convection solar dryers, the air required for product drying is forced through the solar collector to dryer chamber by using a fan or a blower, whereas in the natural convection solar dryers, it is due to 
natural action or buoyancy force action. The indirect solar dryer is the oldest type of solar dryers which consists of a separate solar collector with a transparent cover (glass sheet) on the top and a drying unit with an opaque cover on the top. These dryers are not standardized; they fulfill the special requirements for drying different products. In the present study, ginger samples of a constant mass (150 g) have been dried in an indirect forced convection solar dryer under the meteorological conditions of Hisar $\left(29^{\circ} 5^{\prime} 5^{\prime} \mathrm{N}\right.$ latitude and $75^{\circ} 45^{\prime} 55^{\prime} \mathrm{E}$ longitude), India. For obtaining more accurate results, the experiment was repeated three times, namely, first sample drying, second sample drying, and third sample drying. The convective and the evaporative heat transfer coefficients of ginger dried under the forced convection mode have been evaluated which will be required for the design of an optimum dryer. The solar collector efficiency has also been evaluated.

\section{MATERIAL AND METHODS}

\subsection{Experimental setup}

The schematic view of the forced convection indirect solar dryer is shown in Fig. 1. It mainly consists of a solar air collector for heating the air, a drying chamber containing wet product to dry, and a chimney fitted with an induced fan provided at the top of the drying chamber.

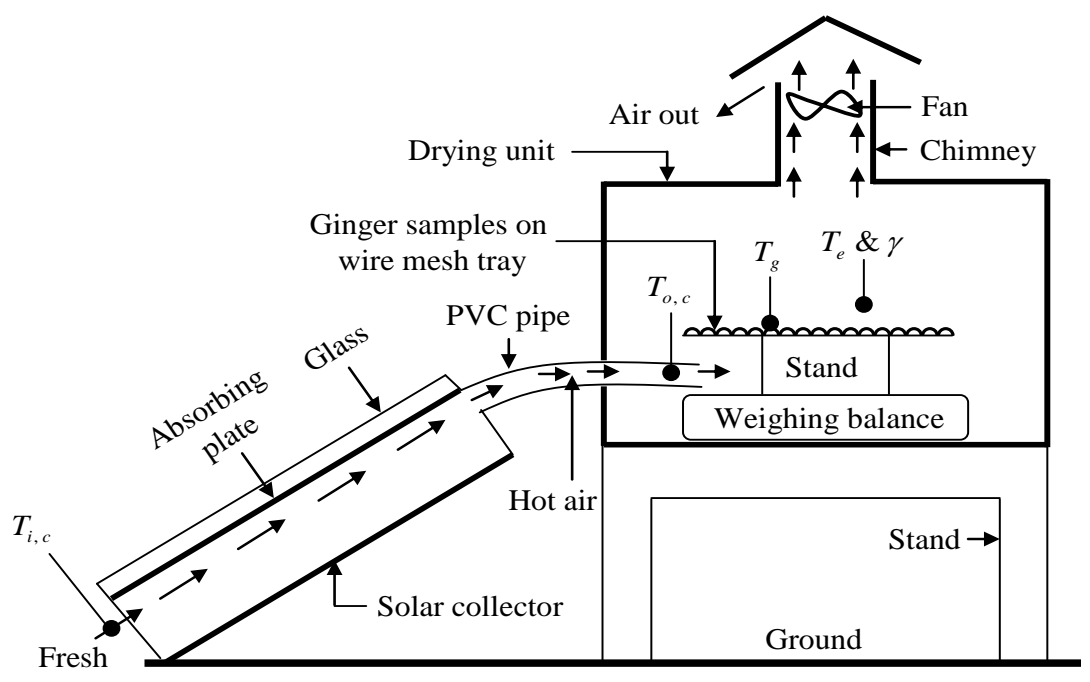

air in

Fig. 1 Schematic view of indirect forced convection solar dryer

The design details of the solar collector and the cabinet dryer are given in Table 1. The solar air collector consists of a black coated galvanized iron sheet which heats up the air. The back part and side walls of the solar air collector have been insulated with glass wool. To achieve the desired glazing effects a transparent $8 \mathrm{~mm}$ thick glass sheet was fitted over the top of the collector. The drying chamber of size $0.4 \mathrm{~m} \times 0.45 \mathrm{~m} \times 0.5 \mathrm{~m}$ was thermally insulated with glass wool to minimize heat losses. The heated air in the collector was made to flow to 
the drying chamber through the glass wool insulated PVC pipe of $5 \mathrm{~cm}$ in diameter and of $40 \mathrm{~cm}$ in length. A rectangular shaped wire mesh tray of size $0.08 \mathrm{~m} \times 0.20 \mathrm{~m}$ was used to accommodate the evenly placed ginger pieces of known mass in a single thin layer. The weight reduction of the ginger samples due to the evaporation of moisture by hot air was measured by using an electronic weighing balance (model TJ - 6000, capacity $6 \mathrm{~kg}$, least count of $0.1 \mathrm{~g}$ ) placed inside the cabinet dryer.

Table 1 Design details of solar air heater and cabinet dryer

\begin{tabular}{|c|c|}
\hline S. No. Details of solar dryer & Dimensions/Specifications \\
\hline 1. Total area of flat plate collector & $1.3 \mathrm{~m} \times 1 \mathrm{~m}$ \\
\hline 2. Aperture area of collector & $1.26 \mathrm{~m} \times 0.95 \mathrm{~m}$ \\
\hline 3. Air inlet passage to the collector & $0.5 \mathrm{~m} \times 0.07 \mathrm{~m}$ \\
\hline 4. Collector inclination (Tilt angle) & $30^{\circ}$ \\
\hline 5. Absorber plate & GI sheet, $1.2 \mathrm{~mm}$ thick \\
\hline 6. Bottom side of collector & $1.2 \mathrm{~cm}$ thick wooden plate \\
\hline 7. Glass thickness & $8 \mathrm{~mm}$ \\
\hline 8. Cabinet dryer & $0.4 \mathrm{~m} \times 0.45 \mathrm{~m} \times 0.5 \mathrm{~m}$ \\
\hline 9. Tray size & $0.08 \mathrm{~m} \times 0.20 \mathrm{~m}$ \\
\hline 10. Fan (DC Brushless, 12 VDC) & $1.4 \mathrm{~W}, 2700 \pm 300 \mathrm{RPM}$ \\
\hline 11. Solar panel (36 number of cells) & $1.2 \mathrm{~m} \times 0.5 \mathrm{~m} \times 0.03 \mathrm{~m}$ \\
\hline 12. Battery (12 V Lead Acid) & $18 \mathrm{~cm} \times 7.5 \mathrm{~cm} \times 16.5 \mathrm{~cm}$ \\
\hline
\end{tabular}

\subsection{Sample preparation}

Fresh ginger purchased from local market was washed, peeled, and cylindrically-shaped with $1.5 \mathrm{~cm}$ in diameter and $3 \mathrm{~cm}$ in length. The slices were kept at ambient for one and half hour to remove surface moisture. The samples were accommodated in a rectangular shaped wire mesh tray which was directly placed on the weighing balance.

\subsection{Experimental procedure and instrumentation}

Experimental observations were recorded during day time (between 9 AM to 6 PM) in the month of March 2015 at Guru Jambheshwar University of Science and Technology, Hisar. Experimental observations were recorded at every 1 hour time interval. The following steps were followed for the experimentation:

(i) Accurately measured fresh ginger mass samples of $150 \mathrm{~g}$ was accommodated on a rectangular shaped wire mesh tray $(0.08 \mathrm{~m} \times 0.20 \mathrm{~m})$ placed on the weighing balance.

(ii) A digital humidity meter (Model HT - 315) was used to measure temperature $\left(T_{e}\right)$ and relative humidity ( $\gamma$ or $\mathrm{RH}$ ) just above the ginger samples. It was started 1 minute before recording the observations.

(iii) Dryer inlet temperature $\left(T_{o, c}\right)$, product surface temperature $\left(T_{g}\right)$, collector inlet air temperature $\left(T_{i, c}\right)$, and absorbing plate average temperatures $\left(T_{s, a v}\right)$ of the collector were measured by using calibrated thermocouples attached to the digital temperature meter (accuracy $\pm 0.1^{\circ} \mathrm{C}$ ).

(iv) The air flow at the collector inlet air passage was measured by using a digital anemometer (model AM-4201) having the least count of $0.1 \mathrm{~m} / \mathrm{s}$. 
(v) The quantity of moisture content evaporated $\left(m_{e v}\right)$ from the ginger samples during drying time interval was obtained by the difference in weight of the consecutive readings which was measured by a digital weighing balance (model TJ - 6000, capacity $6 \mathrm{~kg}$, least count of $0.1 \mathrm{~g})$.

(vi) The solar intensity data ( $I$ ) have been collected hourly at CCSHAU, Hisar.

(vii) All the hourly data during the experiments were recorded from 9.00 AM to 6.00 PM.

(viii) For obtaining better accuracy in the results the experiments were repeated thrice.

\subsection{Thermal modeling}

The rate of heat utilized to evaporate moisture is given as [16-18]:

$$
\dot{Q}_{e}=0.016 h_{c}\left[P\left(T_{g}\right)-\gamma P\left(T_{e}\right)\right]
$$

Convective heat transfer coefficient $\left(h_{c}\right)$ can be determined as [17],

$$
\begin{gathered}
h_{c}=\left(K_{v} / X\right) C(\operatorname{Re} \operatorname{Pr})^{n} \\
\dot{Q}_{e}=0.016\left(K_{v} / X\right) C(\operatorname{Re} \operatorname{Pr})^{n}\left[P\left(T_{g}\right)-\gamma P\left(T_{e}\right)\right]
\end{gathered}
$$

where $X$ is the characteristic dimension in $\mathrm{m}$.

$$
m_{e v}=0.016\left(K_{v} / X \lambda\right) C(\operatorname{Re} \operatorname{Pr})^{n}\left[P\left(T_{g}\right)-\gamma P\left(T_{e}\right)\right] A_{t} t
$$

where $A_{t}$ is the area of tray in $\mathrm{m}^{2}$ and $t$ is time in seconds.

$$
\begin{aligned}
& \text { Let } 0.016\left(K_{v} / X \lambda\right)\left[P\left(T_{g}\right)-\gamma P\left(T_{e}\right)\right] A_{t} t=Z \\
& \therefore\left[m_{e v} / Z\right]=C(\operatorname{RePr})^{n} \\
& \ln \left[m_{e v} / Z\right]=\ln C+n \ln (\operatorname{Re} \mathrm{Pr})
\end{aligned}
$$

Eq. (6) is the form of a linear equation,

$$
y=m x+c
$$

where $y=\ln \left(m_{e v} / Z\right), m=n, x=\ln (\operatorname{Re} \operatorname{Pr})$ and $c=\ln C$. Thus, $C=e^{c}$.

Values of $m$ and $c$ in Eq. (7) are obtained by using the simple linear regression formulae. Evaporative heat transfer coefficients $\left(h_{e}\right)$ were calculated as [18],

$$
h_{e}=0.016 h_{c}\left[\left\{P\left(T_{g}\right)-\gamma P\left(T_{e}\right)\right\} /\left(T_{g}-T_{e}\right)\right]
$$

The thermo-physical properties, namely, specific heat $\left(C_{v}\right)$, thermal conductivity $\left(K_{v}\right)$, density $\left(\rho_{v}\right)$, viscosity $\left(\mu_{v}\right)$, and partial vapor pressure $P(T)$ of humid air were evaluated for mean temperature $T_{i}=\left[\left(T_{g}+T_{e}\right) / 2\right]$ by using the following Eqs. [16-18]:

$$
\begin{gathered}
C_{v}=999.2+0.1434 T_{i}+1.101 \times 10^{-4} T_{i}^{2}-6.7581 \times 10^{-8} T_{i}^{3} \\
K_{v}=0.0244+0.7673 \times 10^{-4} T_{i}
\end{gathered}
$$




$$
\begin{gathered}
\rho_{v}=353.44 /\left(T_{i}+273.15\right) \\
\mu_{v}=1.718 \times 10^{-5}+4.620 \times 10^{-8} T_{i} \\
P(T)=\exp \left[25.317-5144 /\left(T_{i}+273.15\right)\right]
\end{gathered}
$$

\subsection{Solar air collector efficiency}

Solar air collector efficiency $\left(\eta_{c}\right)$ was calculated as the ratio of total amount of heat at solar flat plate collector outlet $\left(Q_{o}\right)$ to the total amount of heat received by solar flat plate collector $\left(Q_{i}\right)$ as [19]:

$$
\begin{gathered}
\eta_{c}=Q_{o} / Q i \\
Q_{o}=V_{o} \times A_{o, c} \times \rho_{v} \times\left(T_{o, c}-T_{i, c}\right) \times C_{v} \\
Q_{i}=I \times A_{c}
\end{gathered}
$$

\subsection{Experimental error}

The experimental error was evaluated in terms of percent uncertainty (internal + external) for the mass of moisture evaporated. The following equations were used for internal uncertainty [18]:

$$
U_{I}=\sqrt{\left(\sigma_{1}^{2}+\sigma_{2}^{2}+\ldots \sigma_{N}^{2}\right)} / N_{o}
$$

where $\sigma$ is the standard deviation and $N_{o}$ denotes the number of sets.

$$
\% \text { internal uncertainty }=\left(U_{I} / \text { mean of the total observations }\right) \times 100
$$

For external uncertainty, the least counts of all the instruments used in measuring the observation data were considered.

\section{RESULTS AND DISCUSSION}

The experimental data collected for ginger drying under induced forced convection mode in an indirect solar dryer for three samples of constant mass $(150 \mathrm{~g})$ are given in Tables 1 to 3 .

Table 1 Data of $1^{\text {st }}$ sample ginger drying in an indirect solar dryer (March 29, 2015)

\begin{tabular}{ccccccccc}
\hline $\begin{array}{c}\text { Time } \\
\text { (hour) }\end{array}$ & $\begin{array}{c}T_{g} \\
\left({ }^{\circ} \mathrm{C}\right)\end{array}$ & $\begin{array}{c}T_{e} \\
\left({ }^{\circ} \mathrm{C}\right)\end{array}$ & $\begin{array}{c}\gamma \\
(\%)\end{array}$ & $\begin{array}{c}m_{e v} \\
(\mathrm{~g})\end{array}$ & $\begin{array}{c}T_{s, a v} \\
\left({ }^{\circ} \mathrm{C}\right)\end{array}$ & $\begin{array}{c}T_{i, c} \\
\left({ }^{\circ} \mathrm{C}\right)\end{array}$ & $\begin{array}{c}T_{o, c} \\
\left({ }^{\circ} \mathrm{C}\right)\end{array}$ & $\begin{array}{c}I \\
\left(\mathrm{~W} / \mathrm{m}^{2}\right)\end{array}$ \\
\hline 0 & 27.1 & 26.8 & 50.2 & - & 34.8 & 25.8 & 37.5 & 441 \\
1 & 36.8 & 35.1 & 33.9 & 11.8 & 49.6 & 30.2 & 54.3 & 662 \\
2 & 43.4 & 40.7 & 21.5 & 12.6 & 58.2 & 33.6 & 64.2 & 802 \\
3 & 46.2 & 43.0 & 18.3 & 17.4 & 63.3 & 35.1 & 69.1 & 862 \\
4 & 48.3 & 44.8 & 15.9 & 18.7 & 64.0 & 36.3 & 70.2 & 903 \\
5 & 49.7 & 45.9 & 14.2 & 16.5 & 62.9 & 36.7 & 69.5 & 865 \\
6 & 48.4 & 44.8 & 13.6 & 12.4 & 58.5 & 36.2 & 63.8 & 588 \\
7 & 44.7 & 41.5 & 16.3 & 8.4 & 51.1 & 35.1 & 55.6 & 473 \\
8 & 39.6 & 37.2 & 21.9 & 6.7 & 43.8 & 33.2 & 46.7 & 215 \\
9 & 34.4 & 32.6 & 26.7 & 5.2 & 35.1 & 31.0 & 35.8 & 85 \\
\hline
\end{tabular}


Table 2 Data of $2^{\text {nd }}$ sample ginger drying in an indirect solar dryer (March 30, 2015)

\begin{tabular}{ccccccccc}
\hline $\begin{array}{c}\text { Time } \\
\text { (hour) }\end{array}$ & $\begin{array}{c}T_{g} \\
\left({ }^{\circ} \mathrm{C}\right)\end{array}$ & $\begin{array}{c}T_{e} \\
\left({ }^{\circ} \mathrm{C}\right)\end{array}$ & $\begin{array}{c}\gamma \\
(\%)\end{array}$ & $\begin{array}{c}m_{e v} \\
(\mathrm{~g})\end{array}$ & $\begin{array}{c}T_{s, a v} \\
\left({ }^{\circ} \mathrm{C}\right)\end{array}$ & $\begin{array}{c}T_{i, c} \\
\left({ }^{\circ} \mathrm{C}\right)\end{array}$ & $\begin{array}{c}T_{o, c} \\
\left({ }^{\circ} \mathrm{C}\right)\end{array}$ & $\begin{array}{c}I \\
\left(\mathrm{~W} / \mathrm{m}^{2}\right)\end{array}$ \\
\hline 0 & 27.6 & 26.1 & 52.3 & - & 36.3 & 23.8 & 35.8 & 469 \\
1 & 36.1 & 34.4 & 31.8 & 12.3 & 50.3 & 27.0 & 53.7 & 680 \\
2 & 42.9 & 40.1 & 20.2 & 14.1 & 57.1 & 30.3 & 61.5 & 810 \\
3 & 45.2 & 42.2 & 18.6 & 15.2 & 65.3 & 32.4 & 68.6 & 891 \\
4 & 47.8 & 44.4 & 17.7 & 16.1 & 66.0 & 34.7 & 70.8 & 911 \\
5 & 48.7 & 45.1 & 15.8 & 14.2 & 63.2 & 33.5 & 69.4 & 798 \\
6 & 47.2 & 43.8 & 14.9 & 12.2 & 61.7 & 33.2 & 61.9 & 774 \\
7 & 45.1 & 41.8 & 16.3 & 8.4 & 50.8 & 31.9 & 51.7 & 406 \\
8 & 40.2 & 37.5 & 18.9 & 6.1 & 42.5 & 30.0 & 41.6 & 185 \\
9 & 35.6 & 33.6 & 24.2 & 5.1 & 38.3 & 27.4 & 31.9 & 81 \\
\hline
\end{tabular}

Table 3 Data of $3^{\text {rd }}$ sample ginger drying in an indirect solar dryer (March 31, 2015)

\begin{tabular}{ccccccccc}
\hline $\begin{array}{c}\text { Time } \\
\text { (hour) }\end{array}$ & $\begin{array}{c}T_{g} \\
\left({ }^{\circ} \mathrm{C}\right)\end{array}$ & $\begin{array}{c}T_{e} \\
\left({ }^{\circ} \mathrm{C}\right)\end{array}$ & $\begin{array}{c}\gamma \\
(\%)\end{array}$ & $\begin{array}{c}m_{e v} \\
(\mathrm{~g})\end{array}$ & $\begin{array}{c}T_{s, a v} \\
\left({ }^{\circ} \mathrm{C}\right)\end{array}$ & $\begin{array}{c}T_{i, c} \\
\left({ }^{\circ} \mathrm{C}\right)\end{array}$ & $\begin{array}{c}T_{o, c} \\
\left({ }^{\circ} \mathrm{C}\right)\end{array}$ & $\begin{array}{c}I \\
\left(\mathrm{~W} / \mathrm{m}^{2}\right)\end{array}$ \\
\hline 0 & 27.9 & 26.5 & 55.3 & - & 37.1 & 24.9 & 37.9 & 521 \\
1 & 36.5 & 34.8 & 33.0 & 11.8 & 49.5 & 28.4 & 54.1 & 637 \\
2 & 43.2 & 40.3 & 21.0 & 13.2 & 57.5 & 31.6 & 63.7 & 817 \\
3 & 45.7 & 42.6 & 18.0 & 16.1 & 66.5 & 33.9 & 72.8 & 911 \\
4 & 48.1 & 44.6 & 17.7 & 16.6 & 66.6 & 35.3 & 72.9 & 912 \\
5 & 49.2 & 45.4 & 15.0 & 14.7 & 64.3 & 34.7 & 71.3 & 825 \\
6 & 47.8 & 44.2 & 14.0 & 11.9 & 60.5 & 34.9 & 61.8 & 636 \\
7 & 44.9 & 41.6 & 17.0 & 8.2 & 49.5 & 32.4 & 50.5 & 343 \\
8 & 39.9 & 37.3 & 21.0 & 5.7 & 41.3 & 31.5 & 42.4 & 173 \\
9 & 35.0 & 33.1 & 26.0 & 4.5 & 37.4 & 28.3 & 32.7 & 79 \\
\hline
\end{tabular}

The data given in Tables 1 to 3 were used to determine the values of constants $C$ and $n$ in the Nusselt number expression by simple linear regression method. The values of these coefficients were used in Eq. (2) for evaluating the values of the convective heat transfer coefficients. The values of the convective heat transfer coefficients were used in Eq. (8) for determining the values of the evaporative heat transfer coefficients. The efficiency of solar air collector has also been calculated. The evaluated values of the constants $(C$ and $n$ ), convective heat transfer coefficients, evaporative heat transfer coefficients, and solar air collector efficiency are summarized in Table 4 . The product of Reynolds number $(\mathrm{Re})$ and Prandtl number (Pr) has been observed less than equal to $10^{5}$, which indicates that the entire ginger drying for forced indirect solar drying mode falls within a laminar flow [16].

Table 4 Evaluated values of constants, convective and evaporative heat transfer coefficients, and collector efficiency

\begin{tabular}{|c|c|c|c|c|c|c|c|}
\hline $\bar{C}$ & $n$ & $\begin{array}{c}h_{c} \\
\left(\mathrm{~W} / \mathrm{m}^{2}{ }^{\circ} \mathrm{C}\right)\end{array}$ & $\begin{array}{c}h_{c, a v} \\
\left(\mathrm{~W} / \mathrm{m}^{2}{ }^{\circ} \mathrm{C}\right)\end{array}$ & $\begin{array}{c}h_{e} \\
\left(\mathrm{~W} / \mathrm{m}^{2}{ }^{\circ} \mathrm{C}\right)\end{array}$ & $\begin{array}{c}h_{e, a v} \\
\left(\mathrm{~W} / \mathrm{m}^{2}{ }^{\circ} \mathrm{C}\right)\end{array}$ & $\begin{array}{c}\eta_{c} \\
(\%)\end{array}$ & $\begin{array}{l}\eta_{c, a v} \\
(\%)\end{array}$ \\
\hline \multicolumn{8}{|c|}{ First sample drying (29-03-2015) } \\
\hline 0.999 & 0.322 & $4.00-4.06$ & 4.04 & $145.47-181.47$ & 166.79 & $11.60-20.58$ & 14.16 \\
\hline \multicolumn{8}{|c|}{ Second sample drying (30-03-2015) } \\
\hline 0.999 & 0.318 & $3.94-3.98$ & 3.96 & $141.73-174.01$ & 160.36 & $11.53-20.63$ & 14.41 \\
\hline \multicolumn{8}{|c|}{ Third sample drying (31-03-2015) } \\
\hline 0.999 & 0.315 & $3.82-3.87$ & 3.85 & $137.2-165.84$ & 154.25 & $12.37-20.80$ & 14.93 \\
\hline
\end{tabular}


The average value of constant $C$ was evaluated as 0.999 and the values of exponent $n$ were found to vary from 0.315 to 0.322 . The average value of exponent was found to be 0.318 . The values of convective heat transfer coefficients for the dried samples of ginger were observed to vary from 3.82 to $4.06 \mathrm{~W} / \mathrm{m}^{2}{ }^{\circ} \mathrm{C}$. The average value of the convective heat transfer coefficients was found to be $3.95 \mathrm{~W} / \mathrm{m}^{2}{ }^{\circ} \mathrm{C}$. The variation in convective heat transfer coefficients with respect to drying time is illustrated in Fig. 2. Variation in the values of convective heat transfer coefficients for each day of drying is observed almost constant. Different values of convective heat transfer coefficients have been obtained for different ginger drying samples. This variation could be due to change in the operating conditions with drying days. The convective heat transfer coefficients of six crops (green chillies, green peas, white gram, onion, potato, and cauliflower) were reported to vary from crop to crop with a range of $3.5 \mathrm{~W} / \mathrm{m}^{2}{ }^{\circ} \mathrm{C}$ to $26 \mathrm{~W} / \mathrm{m}^{2}{ }^{\circ} \mathrm{C}$ [20]. The evaluated values of the convective heat transfer coefficient of ginger are observed to lie within this range.

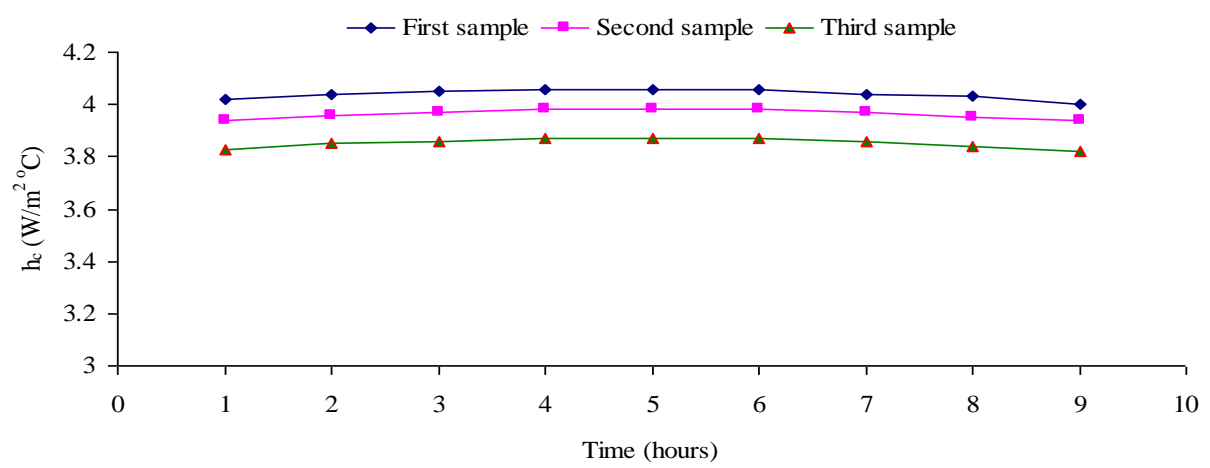

Fig. 2 Variation in convective heat transfer coefficients with time

The values of the evaporative heat transfer coefficients for the dried samples of ginger were observed to vary from 137.2 to $181.47 \mathrm{~W} / \mathrm{m}^{2}{ }^{\circ} \mathrm{C}$. The average value of the evaporative heat transfer coefficients was found to be $160.47 \mathrm{~W} / \mathrm{m}^{2}{ }^{\circ} \mathrm{C}$. The variation in the evaporative heat transfer coefficients with respect to the drying time is illustrated in Fig. 3. Significant

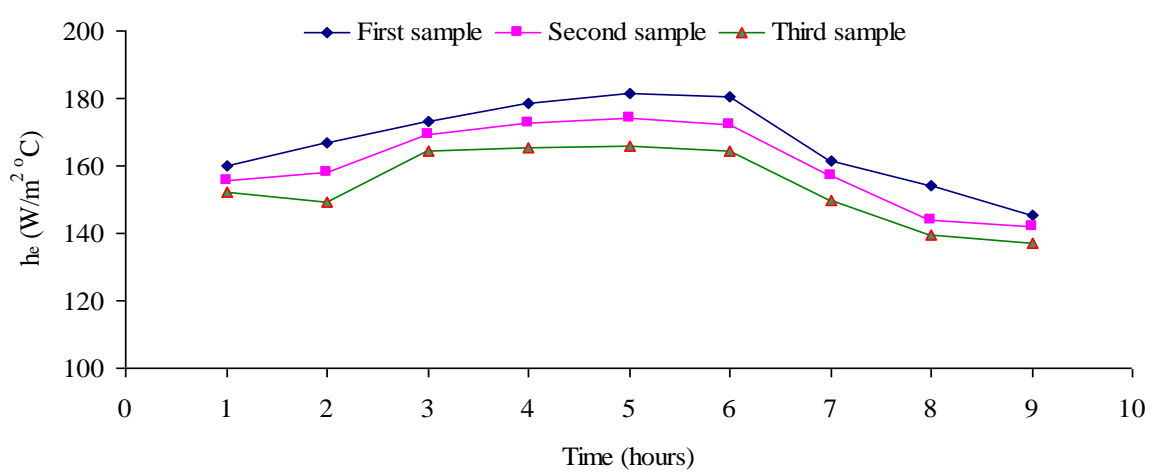

Fig. 3 Variation in the evaporative heat transfer coefficients with time 
variations have been observed in the values of the evaporative heat transfer coefficients for each sample of ginger drying.

The photographic views of the samples of ginger before and after drying are shown in Fig. 4.

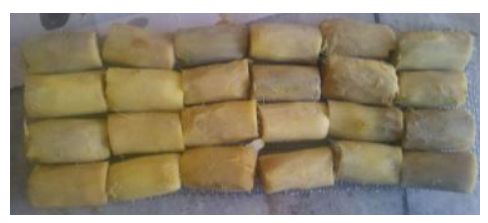

Before drying

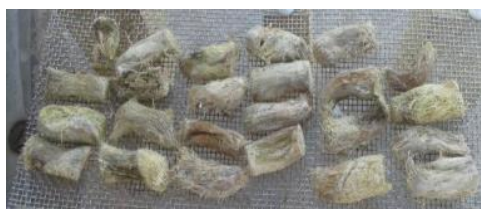

After drying

Fig. 4 Ginger samples before and after drying

For the given days of ginger drying the solar air collector efficiency was observed to vary from $11.53 \%$ to $20.80 \%$. The variation in the collector efficiency with respect to the drying time is shown in Fig. 5. The average value of the collector efficiency was found to be $14.5 \%$.

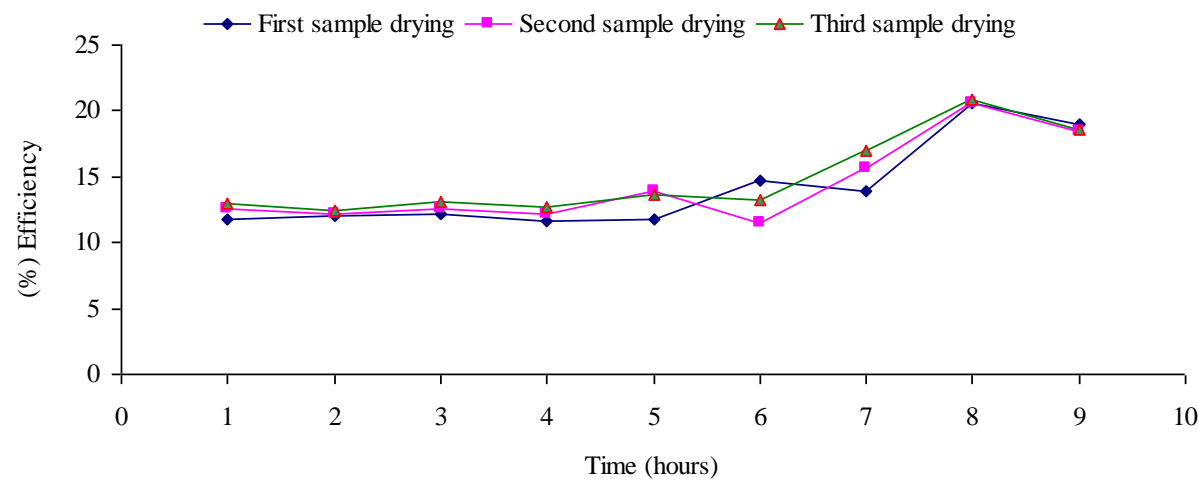

Fig. 5 Variation in solar air collector efficiency with time

The experimental error in terms of percent uncertainty (internal + external) is evaluated as $20.87 \%$. The different values of the convective and the evaporative heat transfer coefficients were found to be within the given range. The error bars (a graphical representation of the variability of data) is used to show the error or uncertainty in the measurement of the convective and the evaporative heat transfer coefficients. It gives a general idea of how precise a measurement is or conversely, how far from the reported value the true value might be. The variability of the convective and the evaporative heat transfer coefficients from their true value are illustrated by error bars $(95 \% \mathrm{CI})$ in Fig. 6 . It is drawn with the help of the SPSS software (version 16.0). 

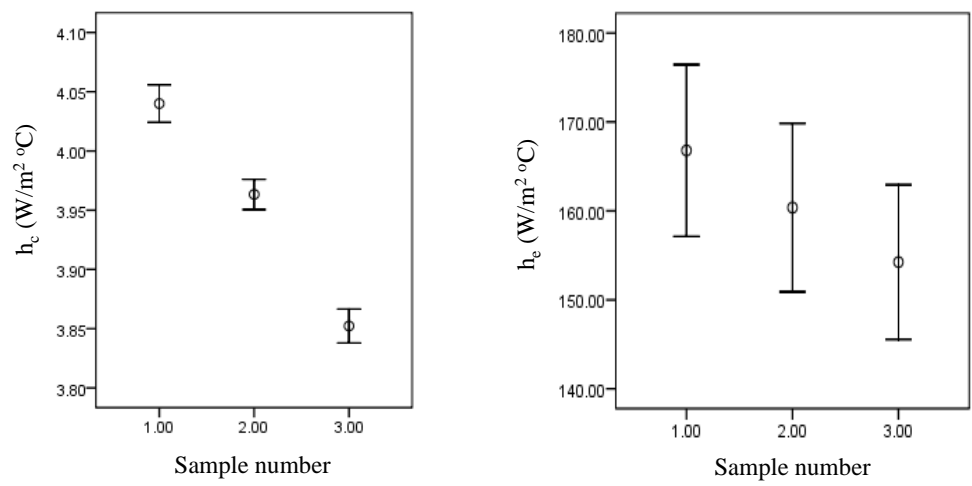

Fig. 6 Error bars

\section{CONCLUSIONS}

In this research, the values of the convective and the evaporative heat transfer coefficients for the forced convection indirect solar drying of ginger for a constant mass have been reported. The experimental data were analyzed by using the Nusselt number expression with the help of simple linear regression analysis. The average values of constant $C$ and exponent $n$ in the Nusselt number expression were found to be 0.999 and 0.318 , respectively. The values of the convective and the evaporative heat transfer coefficients were observed to vary from 3.82 to $4.06 \mathrm{~W} / \mathrm{m}^{2}{ }^{\circ} \mathrm{C}$ and 137.2 to $181.47 \mathrm{~W} / \mathrm{m}^{2}{ }^{\circ} \mathrm{C}$ respectively. The average value of the convective and the evaporative heat transfer coefficients for ginger drying under the forced convection mode inside an indirect solar cabinet dryer was found to be $3.95 \mathrm{~W} / \mathrm{m}^{2}{ }^{\circ} \mathrm{C}$ and $160.47 \mathrm{~W} / \mathrm{m}^{2}{ }^{\circ} \mathrm{C}$, respectively. The solar air collector efficiency was observed to vary from $11.53 \%$ to $20.80 \%$ and its average value was evaluated as $14.5 \%$. The experimental error in terms of percentage uncertainty (internal + external) was calculated to be $20.87 \%$. This research work would be useful in designing a dryer for obtaining high quality dried ginger. It will also be helpful in obtaining an optimum moisture level of ginger for retaining its quality during storage period.

Acknowledgements: The paper is a part of the research done within the project under the scheme of minor research project from the budget head 'DAA, $18 B$ (ii) Research Activities (R\&D) of Guru Jambheshwar University of Science \& Technology (GJUS\&T). The author would like to thank the GJUS\&T for financial support.

\section{REFERENCES}

1. Dohrooc, N.P., Kansal, Ahluwalia, S. N., 2012, Status of soft rot of ginger (zingiber officinale roscoe), Department of vegetable science, Dr Y.S. Parmar University of Horticulture and Forestry, Nauni, Solan (HP), India

2. Jain, N. K., Kothari, S., Mathur, A. N., 2004, Techno-economic evaluation of a forced convection solar dryer, Journal of Agricultural Engineering, 41(3), pp. 6-12.

3. Prasad, J., Prasad, A., Vijay, V., 2006, Studies on the drying characteristics of zingiber officinale under open sun and solar biomass (Hybrid) drying, International Journal of Green Energy, 3, 79-89. 
4. Phoungchandang, S., Nongsang, S., Sanchai, P., 2009, The development of ginger drying using tray drying, heat pump - dehumidified drying, and mixed mode solar drying, Drying Technology, 27(10), pp. 1123-1131.

5. Phoungchandang, S., Saentaweesuk, S., 2011, Effect of two stage, tray and heat pump assisteddehumidified drying on drying characteristics and qualities of dried ginger, Food and Bioproducts Processing, 89(4), pp. 429-437.

6. Eze, J. I., Agbo, K. E., 2011, Comparative studies of sun and solar drying of peeled and unpeeled ginger, American Journal of Scientific and Industrial research, 2(2), pp. 136-142.

7. Loha, C., Das, R., Choudhury, B., Chatterjee, P., 2012, Evaluation of air drying characteristics of sliced ginger (zingiber officinale) in a forced convective cabinet dryer and thermal conductivity measurement, Journal of Food Processing \& Technology, 3(6), 5p (doi: 10.4172/2157-7110.1000160).

8. Bhagat, H. A., Lawankar, S. M., 2012, Experimental study of PV powered forced circulation solar dryer with and without reflective mirror, Journal of Information, Knowledge and Research in Mechanical Engineering, 2(1), pp. 88-93.

9. Hogue, M. A., Bala, B. K., Hossain, M. A., Uddin, M. B., 2013, Drying kinetics of ginger rhizome (Zingiber officinale), Bangladesh Journal of Agricultural, 38(2), pp. 300-319.

10. Fudholi, A., Ruslan, M. H., Othman, M. Y., Zaharim, A., Sopian, K., 2013, Mathematical modelling of solar drying of thin layer ginger, Latest Trends in Renewable Energy and Environmental Informatics, pp. 273-278

11. Sundari, A. U., Neelamegam, P., Subramanian, C., 2013, Study and analysis of drying characteristics of ginger using solar drier with evacuated tube collectors, Research Journal of Pharmaceutical, Biological and Chemical Sciences, 4(3), pp. 1258-1267.

12. Deshmukh, A. W., Varma, M. N., Yoo, C. K., Wasewar, K. L., 2013, Effect of ethyl oleate pretreatment on drying of ginger: characteristics and mathematical modelling, Journal of Chemistry, 2013, 6p. (http://dx.doi.org/10.1155/2013/890384)

13. Mehta, A., Jain, S., Kothari, S., Jain, S. K., 2013, Performance of solar convection type solar dryer with thermal storage for ginger drying, International Journal of Agricultural Engineering, 6(1), pp. 14-19.

14. Jayashree, E., Visvanathan, R., John Zachariah, T., 2014, Quality of dry ginger (Zingiber Officinale) by different drying methods, Journal of Food Science Technology, 51 (11), pp. 3190-3198.

15. Deshmukh, A. W., Varma, M. N., Yoo, C. K., Wasewar, K. L., 2014, Investigation of solar drying of ginger (Zingiber Officinale): Empirical modelling, drying characteristics, and quality study, Chinese Journal of Engineering, 2014, 7p (http://dx.doi.org/10.1155/2014/305823).

16. Kumar, M., 2012, Effect of internal heating of sensible behaviour of sugarcane juice in a stainless steel pot, Facta Universitatis, series: Mechanical Engineering, 10(2), pp. 13-124.

17. Kumar, M., 2013, Forced convection greenhouse papad drying: An experimental study, Journal of Engineering Science and Technology, 8(2), pp. 191-207.

18. Kumar, M., Prakash, O., Kasana, K. S., 2012, Experimental investigation on natural convective heating of milk, Journal of Food Process Engineering, 35, pp. 715-726.

19. Pangavhane, D., Sawhney, R., Sarsavadia, P., 2002, Design, development and performance testing of a new natural convection solar dryer, Energy, 27, pp. 579-590.

20. Anwar, S. I., Tiwari, G. N., 2001, Evaluation of convective heat transfer coefficient in crop drying under open sun drying, Energy Conversion and Management, 42(5), pp. 627-637. 